\title{
BENTUK PENERAPAN DAKWAH PERSUASIF TERHADAP PEMBINAAN EKS PEKERJA SEKS KOMERSIAL DI PANTI SOSIAL KARYA WANITA MATTIRODECENG KOTA MAKASSAR
}

\author{
ST. Aisyah, BM \\ Muliaty Amin \\ Abd. Rasyid Masri \\ Usman Jasad \\ Fakultas Dakwah dan Komunikasi UIN Alauddin Makassar
}

\begin{abstract}
Abstrak: Tulisan ini fokus pada bentuk penerapan dakwah persuasif terhadap pembinaan eks pekerja seks komersial yang terdeskripsi pada dakwah fardiiyah yaitu; pembinaan tablig Islam (taujiyah dan tablig kitabah), pembinaan secara Irsyad Islam (bimbingan dakwah, penyuluhan Islam), tadbir Islam meliputi; manajemen (lembaganya), pembinaan takwim.

Penelitian ini menggunakan metode kualitatif tentang metode dakwah persuasif dalam bentuk dakwah farḍiyah terhadap pembinaan eks pekerja seks komersial di Panti Sosial Karya Wanita Mattirodeceng Kota Makassar. Pendekatan utama yang digunakan adalah pendekatan ilmu dakwah disertai pendekatan multidisipliner meliputi pendekatan sosiologis, pendekatan komunikasi, dan pendekatan psikologis. Sumber data atau informannya 12 orang dengan rincian petugas atau pekerja sosial (Peksos) sebanyak 6 orang dan eks pekerja seks komersial sebanyak 6 orang. Data dikumpulkan dengan metode observasi, wawancara, dan dokumentasi dengan instrumen penelitian adalah peneliti sendiri dan dibantu dengan pedoman wawancara, matriks perencanaan penelitian, alat-alat dokumentasi, berupa alat perekam (voice recorder), kamera serta alat tulis sebagai catatan dalam proses perekaman data di lapangan. Teknik analisis data yang digunakan dalam penelitian ini dengan menggunakan teori Miles and Hubermen adalah reduksi data (data reduction), penyajian data (data display), dan penarikan kesimpulan (conclusion drawing/verification).

Hasil penelitian menunjukkan bahwa bentuk penerapan dakwah persuasif terhadap pembinaan eks pekerja seks komersial yaitu; a). penyampaian dakwah persuasif dalam bentuk pemberian bimbingan sosial; integritas diri dan materi dakwah, b). penyampaian dakwah persuasif dalam bentuk bimbingan lanjutan, c). penerapan dakwah persuasif dalam bentuk fardiyah; pembinaan dalam bentuk tablig Islam, pembinaan dalam bentuk taujiyah, pembinaan dalam bentuk tablig khitabah, pembinaan dalam bentuk irsyad islam; kegiatan bimbingan dakwah, pembinaan dengan takwin; memiliki kemampuan dalam berkomunikasi, memiliki kemampuan dalam melakukan bimbingan sosial, memiliki kemampuan dalam pemberian bimbingan keterampilan.
\end{abstract}

Keywords: Dakwah Persuasif, Tajuiya, Irsyad, Takwim

\section{PENDAHULUAN}


Sasaran kegiatan dakwah yaitu seluruh anggota masyarakat dengan segala macam komponen di dalam sistem dakwah. Usaha-usaha untuk melakukan internaslisasi dan sosialisasi ajaran-ajaran Islam dalam proses dakwah ditujukan kepada sasaran atau obyek dakwah. Manusia sebagai obyek dakwah dapat dikelompokkan secara psikologis dan sosiologis. Secara psikologis manusia memiliki beberapa aspek, yaitu sifat-sifat kepribadian (personality traits), intelegensia, pengetahuan (knowledge), keterampilan (skill), nilai-nilai (values), dan peranan (roles). Secara sosiologis manusia dapat dibedakan atas beberapa aspek, yaitu nilai-nilai, adat dan tradisi, pengetahuan, keterampilan, bahasa (language), dan milik kebendaan (material possesions). Manusia sebagai makhluk individu memiliki tiga macam kebutuhan yang harus dipenuhi secara seimbang, yaitu kebutuhan kebendaan (materi), kebutuhan kejiwaan (spritual), dan kebutuhan kemasyarakatan (sosial). Sebagai makhluk sosial, manusia terikat oleh tiga dimensi pokok, yaitu dimensi kultural (kebudayaan dan peradaban), dimensi struktural (bentuk bangunan hubungan sosial), dan dimensi normatif (tata krama dalam pergaulan hidup sosial).

Fenomena pekerja seks komersial menjadi bagian sisi kehidupan masyarakat perkotaan yang merupakan obyek atau sasaran dakwah. Pesatnya perkembangan di kota mendorong kompleksitas, spesifikasi dan differensiasi kerja. Tuntutan ekonomi sebagai harmonisasi interaksi yang satu sisi memuluskan praktek prostitusi dalam bingkai dinamika perkotaan meskipun praktek demikian menyimpang dari norma kesusilaan, bertentangan dengan nilai-nilai keagamaan akan tetapi semakin tumbuh dan berkembang di kota-kota di Indonesia, termasuk di Kota Makassar.

Kota Makassar didefinisikan sebagai kota jasa (tinjauan history), dimana pertumbuhan dan mobilitas penduduk semakin hari semakin meningkat, menjadikan destinasi ekonomi di Kawasan Indonesia Timur. Secara eksplisit prostitusi pun menjadi bagian dari destinasi tersebut. Sebagian masyarakat menyadari bahwa di satu sisi praktek prostitusi menjadi pendukung utama dalam bisnis hiburan yang menawarkan kesenangan, pemenuhan syahwat. Kehadiran pekerja seks komersial menjadi komoditas ekonomi yang mendatangkan keuntungan financial. Dan juga merupakan pemicu maraknya tempat prostitusi yang melahirkan transaksi ekonomi yang cukup fantastis. Kota Makassar memiliki beberapa lokalisasi sebagai tempat hiburan malam yang identik dengan praktek prostitusi seperti di sekitar kawasan Pelabuhan Sukarno Hatta yang dikenal jalan Nusantara, taman makam pahlawan (sebagai kawasan pekerja seks komersial menjajakan dirinya), jalan sungai saddang, bahkan terdapat beberapa hotel yang menyediakan pekerja seks komersial dengan fasilitas kamar shorttime bagi penjaja seks. Penyimpangan seks tersebut tanpa disadari akan menciptakan diskriminasi, kemelaratan, eksploitasi dan ketidakadilan gender.

Secara hukum fenomena sosial pekerja seks komersial muncul secara luas disebabkan; pertama tidak jelasnya undang-undang yang melarang praktek pelacuran, prostitusi dan lain-lain, kedua merosotnya norma-norma susila dan keagamaan, ketiga era dan zaman modern menimbulkan budaya eksploitasi, keempat tekanan ekonomi dan faktor kemiskinan. ${ }^{1}$

Pekerja seks komersial dan segala bentuk praktiknya dikorelasikan dengan faktor ekonomi. Pekerja seks komersial sebagai makhluk sosial dan individu tentu sama dengan manusia lainnya yang ingin mencukupi kebutuhan hidupnya, berupa materi yang tentu juga butuh kenyamanan kejiwaan sehingga untuk mencapainya dilakukan

\footnotetext{
${ }^{1}$ Kartini Kartono, Patologi Sosial (Jakarta: Rajawali Pers, 2009) h. 183.
} 
dengan segala cara tanpa mempertimbangkan halalnya dalam mencari rejeki yang tidak layak menurut pandangan Islam. Tingkah laku yang tidak sesuai dengan nilai, melakukan pelanggaran terhadap norma merupakan praktek atau prilaku deviant. Olehnya pekerja seks komersial dianggap perilaku deviasi, gejala penyakit sosial yang membutuhkan penanganan dengan intervensi sosial yang sistematis, humanis, terukur dan berkelanjutan, serta membutuhkan peran serta berbagai pihak. Sejalan dengan itu, untuk membendung berkembangnya praktek prostitusi, berbagai upaya dan usaha pemerintah untuk meminimalisir bahkan memberantas prostitusi baik secara hukum maupun secara persuasif. Selama ini, program pembinaan merupakan cara yang terbaik dalam menangani persoalan pekerja seks komersial secara khusus. Pembinaan yang meliputi konseling, pembimbingan, pendampingan dan pelatihan melalui panti sosial menjadi ruang dan fasilitas dalam mengedukasi para mantan pekerja seks komersial secara berkelanjutan agar tidak kembali menjalani profesi yang digelutinya, akan tetapi faktanya pembinaan yang dilakukan pemerintah pada lembaga sosial pada panti rehabilitasi belum memberikan efek jerah bagi beberapa mantan pekerja seks komersial meskipun telah melalui proses pembinaan.

Berdasarkan pengamatan awal bahwa selama penjaringan atau razia pekerja seks komersial oleh Satuan Polisi Pamong Praja (Satpol PP), dalam razia tersebut ditemukannya pekerja seks komersial yang merasa diri bukan pekerja seks komersial hanya berjualan makanan dan minuman dan bahkan masih ditemukan pekerja seks komersial yang berulang kali masuk penjaringan atau razia, parahnya mereka pernah dibina oleh panti rehabilitasi. Fenomena sosial yang terjadi pada pekerja seks komersial sangat urgen untuk melakukan peninjauan ulang pada sistem pembinaan yang dilakukan panti rehabilitasi sebab pembinaan yang dilakukan selama ini masih dinilai kurang maksimal, dibutuhkan analisis secara evaluatif dan komprehensif. Sementara itu juga perlu penciptaan metode dan model pembinaan yang lebih tepat sasaran serta pengembangan pendekatan alternatif yang bertujuan meningkatkan kualitas pembinaan.

Fenomena sosial terhadap kasus yang terjadi pasca rehabilitasi mantan pekerja seks komersial, penting adanya kegiatan dakwah yang merupakan kewajiban untuk dilaksanakan secara kifayah, sebagaimana hadis Rasulullah saw. sebagai berikut:

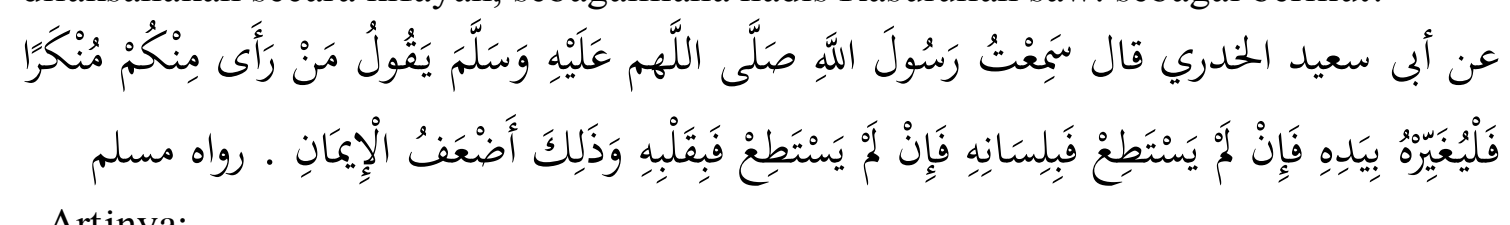

Artinya:

"Dari Abi Sa'id Al-Khudlari radhiyallahu 'anhu dia berkata: Saya mendengar Rasulullah shallallahu 'alaihi wasallam bersabda: "Barangsiapa diantara kamu yang melihat kemungkaran maka hendaklah ia mengubahnya dengan tangannya, jika ia tidak mampu maka dengan lidahnya, jika tidak mampu maka dengan hatinya dan itulah (mengubah kemungkaran dengan hati) selemah-lemah iman“62

\footnotetext{
${ }^{2}$ Kitab Fat-hul Qawiyyil Matin fi Syarhil Arba'in wa Tatimmatul Khamsin (Penjelasan 50 Hadits Inti Ajaran Islam), karya Syaikh 'Abdul Muhsin bin Hamd Al-'Abbad Al-Badr, penerjemah: Ustadz Abu Abdillah Arief Budiman, Lc, h. 43
} 
Hadits tersebut memberikan pencerahan bahwa kegiatan dakwah terhadap pekerja seks komersial wajib dilakukan sebab jika diabaikan tentu semakin meningkat jumlah pekerja seks komersial. Apabila dakwah Islamiah tidak mampu menekan praktek prostitusi, maka keberadaan pekerja seks komersial semakin berkembang subur dan penyakit-penyakit sosial lain semakin tampak, sehingga terciptalah mata rantai yang tidak terputus. Bahkan saling terkait misalnya antara pekerja seks komersial dengan miras, penyalahgunaan narkoba, perjudian, dan proses penularan penyakit HIV (Human Immunodeficiency Virus) dan AIDS (Acquired Immuno Deficiency Syndrome). Berkenaan dengan itu dakwah Islam tetap berjalan seiring dengan berjalannya praktek prostitusi, sehingga diperlukan adanya satu model pendekatan dakwah yang efektif.

Kolaboratif praktek dakwah pada sasaran pembinaan, memberikan efek pencerahaan rohani yang inklusif dan lebih meningkatkan posisi pekerja seks komersial dalam penyikapan problem solving dan decision making. Realitas pelaksanaan obyek dakwah masih berputar dari masjid, mushallah dan instansi pemerintah maupun swasta dan yang dihadapi orang-orang Islam yang banyak memahami dan mengamalkan ajaran Islam. Pada dasarnya, kondisi seperti inilah dakwah harus menjadi instrumen utama dalam menciptakan tatanan kehidupan bermasyarakat dan beragama yang lebih baik, melalui dakwah pula menjadi media edukasi masyarakat dari segala aspek problem manusia, sehingga tidak hanya mengedepankan stigma sosial, tetapi lebih dominan melabelkan secara sosial bahwa pekerja seks komersial identik dengan hal-hal negatif, bahkan termasuk pada saat proses pembinaan, mereka masih dinilai sebagai upaya yang sia-sia, nilai humanistis mengalami degradasi, hilangnya kepekaan sosial terhadap kasus demikian, praktek pembiaran dan kurang perhatian, serta menyalahkan pekerja seks komersial menjadi problematika sulitnya penanganan patologi (penyimpangan) pada konteks masyarakat. Hal ini dikarenakan sebagian masyarakat merasa atau mengganggap bukan bagian dari tanggung jawab sosial seluruh lapisan.

Tulisan ini akan mengkaji tentang bagaimana bentuk penerapan dakwah persuasif terhadap pembinaan eks pekerja seks komersial di Panti Sosial Karya Wanita Mattirodeceng Kota Makassar.

\section{KAJIAN TEORETIK}

\section{A. Konsep Dakwah Fardiyah}

Dakwah Islam dapat dimaknai sebagai usaha dan aktivitas orang beriman dalam mewujudkan ajaran Islam dengan menggunakan sistem dan cara tertentu ke dalam kenyataan hidup perorangan (fardiyah), keluarga (usrah), kelompok (thaifah), masyarakat (mujtama'), dan negara (baldatun). Tanpa adanya aktivitas dakwah, masyarakat muslim tidak mungkin terbentuk. Usaha dakwah Islamiyyah yang mencakup segi-segi yang sangat luas, hal tersebut dapat berlangsung dengan efektif dan efisien, apabila sebelumnya sudah dilakukan dengan tindakan-tindakan persiapan dan perencanaan secara matang. Artinya, dakwah Islam harus terprogramkan secara baik, dan dikerjakan sesuai dengan rencana, dengan tidak apa adanya. Dakwah fardiyah yang pelaksanaanya person to person sebagai upaya menasehati yang ampuh untuk mendekati hati dan memfokuskan diri untuk memperbaiki seseorang.

Dakwah fardiyah sebagai antonim dari dakwah jama'iyah atau 'ammah yaitu berupa ajakan atau seruan ke jalan Allah yang dilakukan oleh seorang dai (penyeru) 
kepada orang lain secara perseorangan dengan tujuan memindahkan al mad'u pada keadaan yang lebih baik dan diridhai oleh Allah. ${ }^{3}$

Selain itu Shaqr mengemukakan defenisi dakwah fardiyah ialah penyampaian ajaran Islam yang ditujukan kepada seseorang secara berhadapan dan bisa terjadi dengan tidak dirancang terlebih dahulu. Dengan definisi ini, dakwah fardiyah berarti interaksi seorang dai dengan seorang mad'u yang berlangsung secara tatap muka dan dialogis sehingga respon mad'u terhadap pesan dan diri dai dapat diketahui seketika, baik secara positif maupun negatif. Tahapan dakwah fardiyah yaitu: a) Mafhum fakwah: usaha seorang dai mengenal dan menjaga hubungan baik dengan mad'u untuk dituntun ke jalan Allah, b) Mafhum haraki (gerakan); menjalin hubungan dengan masyarakat umum, kemudian memilih salah seorang dari mereka untuk membina hubungan lebih dekat, menampakkan kecintaan dan perhatian, 3) Mafhum tanzimi; pengarahan (tanzih) berupa bimbingan seorang dai kepada mad'u dalam rangka berdakwah kepada Allah untuk membantu memahami keadaan dirinya, memahami persoalan-persoalan dan hambatan-hambatan yang dihadapinya, menunjukkan dengan cara halus tentang kemampuan dan kelebihan yang ia miliki. Penegasan (tanzif); dalam hal ini dai membantu penerima dakwah untuk menentukan tempatnya dalam alam islami serta menunjukkan kepadanya kewajiban-kewajiban yang harus dipenuhi pada posisi ini. Penggolongan (tashzif); pengelompokkan sesuatu agar mudah membedakannya antara yang satu dengan yang lainnya. ${ }^{4}$

Dakwah fardiyah sebagai antonim dari dakwah jama'iyah atau 'ammah-ialah ajakan atau seruan ke jalan Allah yang dilakukan seorang dai (penyeru) kepada orang lain secara perseorangan dengan tujuan memindahkan al mad'u pada keadaan yang lebih baik dan diridhai oleh Allah. Perubahan dan perpindahan tersebut adakalanya dari kekafiran kepada keimanan, dari kesesatan dan kemaksiatan kepada petunjuk dan ketaatan, dari sikap amaniyah (individualisme) kepada sikap mencintai orang lain, mencintai kerja sama, dan senang kepada jamaah. Atau adakalanya memindahkannya dari sikap acuh tak acuh dan tidak peduli menjadi sikap komitmen terhadap Islam, baik akhlaknya, adabnya, dan manhaj (system) kehidupannya, yang sudah tentu perpindahan ini menuju arah yang lebih baik dan lebih diridhoi oleh Allah swt. ${ }^{5}$

Dakwah fardiyah inilah salah satu bentuk dakwah yang paling efektif, karena dakwah dilakukan seorang dai (penyeru) kepada orang lain secara perseorangan dengan tujuan memindahkan al mad'u pada keadaan yang lebih baik dan diridhai oleh Allah. Sehingga seorang mad'u dapat memperoleh informasi (ilmu) yang banyak dan langsung bisa mengamalkannya. Perubahan dan perpindahan itu adakalanya dari kekafiran kepada keimanan, dari kesesatan dan kemaksiatan kepada petunjuk dan ketaatan, dari sikap amaniyah (individualisme) kepada sikap mencintai orang lain, mencintai atau kerja sama, dan senang kepada jamaah. Atau adakalanya memindahkannya dari sikap acuh tak acuh dan tidak peduli menjadi sikap komitmen terhadap Islam, baik akhlaknya, adabnya, dan manhaj (sistem) kehidupannya, yang sudah tentu perpindahan ini menuju arah yang lebih baik dan lebih diridhoi Allah swt.

${ }^{3}$ Ali Abdul Halim Mahmud. Dakwah Fardiyah, Metode Membentuk Pribadi Muslim. (Jakarta: Gema Insani Press, 1995), h. 29

${ }^{4}$ Enjang AS. dan Aliyudin. Dasar-Dasar Ilmu Dakwah. (Bandung: Widya Padjajaran, 2009),

h. 67

${ }^{5}$ Enjang AS. dan Aliyudin. Dasar-Dasar Ilmu Dakwah, h. 67 
Jadi, pada dasarnya dakwah fardiyah merupakan salah satu metode dakwah yang paling efektif, karena dakwah dilakukan oleh seorang da'i (penyeru) kepada orang lain secara perseorangan dengan tujuan memindahkan al mad'u pada keadaan yang lebih baik dan diridhai oleh Allah. Sehingga seorang mad'u dapat memperoleh informasi (ilmu) yang banyak dan langsung bisa mengamalkannya.

Juru dakwah dalam dakwah fardiyah memiliki kelebihan khusus, ia harus memunyai skill tersendiri yang memungkinkannya untuk mendidik orang lain, sesuai metode tarbiyah yang telah kita kenal yaitu pengarahan, perencanaan, konsolidasi, penugasan, pemantapan, dan pewarisan. Seorang juru dakwah tidak akan mampu melakukan semua ini kecuali jika dia memiliki keahlian dan kelebihan dalam lapangan amaliah islami pada umumnya dan dalam lapangan dakwah pada khususnya. Tugas yang dijalankan dalam dakwah fardiyah haruslah semata-mata mencari ridho Allah. Dai tidak perlu menunggu atau mengharap keuntungan material maupun spiritual dari seseorang. Ia pun tidak mengharapkan imbalan baik dari perorangan, jamaah, lembaga, atau pemerintah.

Sedangkan al mad'u dalam dakwah fardiyah adalah orang tertentu yang telah dipilih berdasarkan pengetahuan dan pengamatannya karena orang tersebut memunyai tanda-tanda kebaikan, mau menerima dakwah, mencintai peraturan, dan patuh melaksanakan kebaikan serta kemampuannya. Al-mad'u dalam dakwah fardiyah selalu ditemani dan didekati. Dalam hal ini seorang dai berusaha menjalin hubungan yang kuat yang melahirkan rasa persaudaraan semata-mata karena Allah. Juru dakwah dalam dakwah fardiyah juga dituntut untuk senantiasa melayani kepentingan al mad'u tanpa menunggu permintaannya.

\section{B. Dakwah dengan Komunikasi Persuasif}

Dakwah yaitu suatu aktivitas atau kegiatan yang bersifat menyeru atau mengajak kepada orang lain untuk mengamalkan ajaran Islam. Sedangkan tujuan dakwah ialah untuk mengubah masyarakat ke arah kehidupan yang lebih baik, lebih islami, lebih sejahtera lahiriah maupun batiniah. Tujuan dakwah tersebut sesuai dengan tujuan komunikasi persuasif yaitu merubah situasi tersebut yakni merubah kepercayaan, sikap, dan perilaku seseorang dengan menggunakan manipulasi psikologis sehingga orang tersebut bertindak atas kehendaknya sendiri.

Dakwah persuasif sendiri ialah kegiatan berdakwah dengan menggunakan metode komunikasi persuasif yang bertujuan mengubah, memodifikasi atau membentuk respon (sikap atau perilaku) dari penerima atau mad'u. Tujuan itu akan berhasil manakala seorang dai mampu menyampaikan dakwahnya dengan pendekatan psikologis. Salah satu contoh metodologi dakwah dalam Alquran yaitu metode bi alhikmah. Alllah berfirman dalam QS. al-Nahl/16: 125 sebagai berikut:

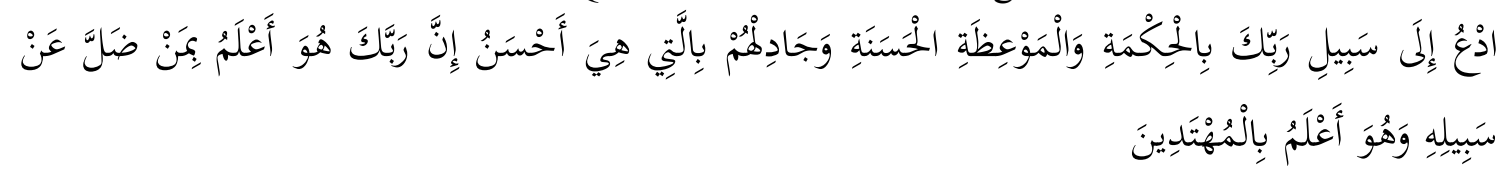

Terjemahnya:

"Serulah (manusia) kepada jalan Tuhanmu dengan hikmah dan pengajaran yang baik, dan berdebatlah dengan mereka dengan cara yang baik. Sesungguhnya 
Tuhanmu, Dialah yang lebih mengetahui siapa yang sesat dari jalan-Nya dan Dialah yang lebih mengetahui siapa yang mendapat petunjuk". ${ }^{6}$

Ayat di atas menjelaskan bahwa ada tiga macam metode dakwah, yaitu bi alhikmah, mujadalah (pengajaran yang baik) dan berdebat dengan baik. Ketiga metode ini sejalan dengan psikologi dakwah. Sementara itu, dakwah bi al-hikmah sendiri merupakan dakwah dengan menggunakan pengetahuan (yang mencerdaskan), dengan cara-cara yang mendekatkan mad'u kepada pengertian dan pemahaman agama yang mendalam, berdakwah dengan cara-cara yang memungkinan penerimaan terhadap pesan dakwah dengan sempurna dan berdakwah dengan cara yang persuasif dan lemah lembut. Sedangkan karakteristik komunikasi persuasif yang ditandai dengan unsur membujuk, mengajak, memengaruhi dan meyakinkan, Hendaknya seorang dai itu berperilaku lembut dan persuasif agar para mad'u itu dapat tertarik atau terpengaruh oleh apa yang telah disampaikan oleh dai.

Di dalam Ilmu komunikasi persuasif juga terdapat istilah-istilah yang memunyai fungsi jalannya komunikasi itu sendiri seperti; Kredibilitas yaitu; cara komunikator menarik perhatian dari komunikan dengan trik-trik yang cukup memungkinkan komunikan, sehingga komunikan dapat bergabung terhadap sikomunikator. Akan tetapi jika komunikasi yang disampaikan tersebut tidaklah sama topiknya dengan komunikan, di sini komunikator harus lebih ekstra dalam membujuk sikomunikan. Afektif yaitu; Pesan atau informasi yang disampaikan oleh komunikator kepada komunikan, secara formal pesan tersebut telah dimengerti oleh sikomunikan. Konotatif yaitu; pesan yang disampaikan dalam bentuk kiasan. Denotatif yaitu; pesan yang artinya jelas dan mempunyai arti dalam informasi tersebut.

Dakwah Islam yang dilakukan dengan cara persuasif dengan tidak melakukan pemaksaan, merusak dan anarkis. Oleh karena itu, dai tidak bisa memaksakan ide-ide dan ajarannya agar diikuti oleh mad'u. Akan tetapi dai seharusnya menyampaikan ide dan ajaran dengan pertimbangan rasa (emosi) dan fakta-fakta yang kuat serta dengan pendekatan kultural berikut dengan bahasa dan idiom-idiomnya. Untuk meningkatkan keberhasilan dalam komunikasi dakwah persuasif perlu dilaksanakan secara sistematis. Dalam komunikasi ada sebuah formula yang dapat dijadikan landasan pelaksanaan komunikasi dakwah persuasif. Formula tersebut adalah: a) Attention yaitu perhatian. Hal ini dilakukan dengan cara menyampaikan informasi dakwah dengan tutur kata yang lembut dan penampilan yang yang berkesan, b) Interest (minat) yaitu menumbuhkan minat mad'u untuk mengenal ajaran agama. Hal ini bisa disentuh dengan menuruti kemauan dan kebutuhan mad'u, c) Desire (hasrat) yaitu menumbuhkan hasrat mad'u dengan cara melakukan kontak visual terhadap mad'u sehingga merasa lebih diperhatikan. Hal tersebut juga menuntut mad'u untuk memperhatikan, d) Decision (keputusan) yaitu upaya untuk mengarahkan mad'u kepada sebuah tindakan yang diinginkan oleh da'i, e) Action (kegiatan) yaitu upaya menggerakkan mad'u untuk melakukan apa yang sudah disampaikan dengan pemilihan kata yang tepat sehingga mudah diapahami oleh mad'u.

Persuasif, yaitu tanpa adanya paksaan dengan memengaruhi jiwa seseorang sehingga dapat membangkitkan kesadarannya untuk menerima dan menerima suatu tindakan. Persuasif berasal dari istilah bahasa Inggris persuation. Persuation dapat

${ }^{6}$ Kementerian Agama, Alquran dan Terjemahnya, (Solo: PT. Tiga Serangkai Mandiri, 2013), 
diartikan sebagai membujuk, merayu, dan meyakinkan. Baik koersif ataupun persuasif, keduanya bertujuan mengubah perilaku, kepercayaan, dan sikap. Bedanya ialah terletak pada cara penyampaiannya. Sedangkan efektif adalah kesempurnaan dalam menyampaikan pesan yang disampaikan, Contohnya yaitu dakwah yang disampaikan oleh Ustaz Maulana yang dapat menggugah pikiran mad'u. Sehingga dapat dikatakan dakwah Persuasif, karena dakwah persuasif adalah proses kegiatan yang memengaruhi jiwa seseorang ( mad' $^{\prime}$ ) sehingga timbul kesadarannya sendiri untuk mengikuti ajakan pendakwah (dai) dengan cara halus atau tanpa paksaan. Tanpa kita sadari dakwah berada di kehidupan kita sehari-hari. Oleh karena itu dalam situasi dan kondisi yang tengah ada dalam masyarakat hendaknya dapat menerapkan metode dakwah manakah yang paling pas untuk digunakan. Dakwah persuasif harus dilakukan oleh orang-orang yang memang memiliki pengetahuan dan keahlian. Dakwah harus tetap dilakukan sekalipun dihadapkan dengan orang yang kemungkinannya sangat kecil untuk berubah.

Sesuai dengan teori Gestalt, seseorang itu dipersepsi sebagai suatu keseluruhan. Oleh karena itu, jika kepribadian seorang muballig sudah dipandang tinggi oleh masyarakat mad'u, maka pesan dakwahnya juga dianggap sebagai bagian dari struktur kepribadiannya. Untuk membuat suatu dakwah persuasif, maka usaha untuk memengaruhi pendapat, pandangan, sikap, atau tingkah laku seseorang dapat ditempuh melalui dua cara: a) Koersif, yaitu dengan cara paksaan bahkan disertai dengan teror yang dapat menekan batin, b) Persuasif, yaitu tanpa adanya paksaan dengan memengaruhi jiwa seseorang sehingga dapat membangkitkan kesadarannya untuk menerima dan menerima suatu tindakan. ${ }^{7}$

Dakwah persuasif menekankan bahwa aktivitas yang dilakukannya dalam bentuk meyakinkan dan menyadarkan mad'u untuk menerima serta melaksanakan pesan-pesan dakwah, sehingga harus menghindarkan diri dari sifat-sifat memaksa, mencerca dan menghina mad'u maupun pihak lain. Dakwah persuasif bertugas menyajikan data dan fakta psikologis maupun sosiologis. Berdasarkan hal itu, mad'u bisa menilai dan membandingkan, yang pada akhirnya menemukan kebenaran serta kesadaran bahwa ajaran Islam merupakan solusi untuk dipilih dan dilaksanakan.

\section{METODOLOGI PENELITIAN}

Penelitian ini menggunakan metode kualitatif. Unit analisis penelitian adalah metode dakwah persuasif dalam bentuk dakwah fardiyah terhadap pembinaan eks pekerja seks komersial di Panti Sosial Karya Wanita Mattirodeceng Kota Makassar. Pendekatan utama yang digunakan adalah berdasarkan ilmu dakwah disertai pendekatan multidisipliner meliputi pendekatan sosiologis, pendekatan komunikasi, dan pendekatan psikologis. Sumber data atau informannya 12 orang dengan rincian petugas atau pekerja sosial (Peksos) sebanyak 6 orang dan eks pekerja seks komersial sebanyak 6 orang. Data dikumpulkan dengan metode observasi, wawancara, dan dokumentasi dengan instrumen penelitian adalah peneliti sendiri dan dibantu dengan pedoman wawancara, matriks perencanaan penelitian, alat-alat dokumentasi, berupa alat perekam (voice recorder), kamera serta alat tulis sebagai catatan dalam proses perekaman data di lapangan. Teknik analisis data yang digunakan dalam penelitian ini dengan menggunakan teori Miles and Hubermen adalah reduksi data (data reduction),

${ }^{7}$ Moh. Ali Aziz, Ilmu Dakwah, h. 446 
penyajian data (data display), dan penarikan kesimpulan (conclusion drawing/verification).

\section{HASIL PENELITIAN DAN PEMBAHASAN}

Fenomena sosial tentang pekerja seks komersial (PSK) dianggap sulit ditangani, namun pemerintah dan masyarakat tetap berupaya untuk menangani masalah tersebut melalui pembinaan Panti Rehabilitasi Mattirodeceng yang ada di Kota Makassar.

Adapun bentuk pembinaan eks pekerja seks komersial dalam penerapan dakwah persuasif yang dilakukan oleh pekerja sosial terhadap eks pekerja seks komersial di Panti Sosial Karya Wanita Mattirodeceng Kota Makassar sebagai berikut:

1. Penyampaian dakwah persuasif dalam bentuk bimbingan sosial.

Penyampaian dakwah persuasif dalam bentuk bimbingan sosial yaitu bimbingan fisik, bimbingan mental, dan bimbingan vokasional yang diterapkan pekerja sosial kepada klien berdasarkan aturan Panti Sosial Karya Wanita Mattirodeceng Kota Makassar. Hal tersebut senada yang disampaikan oleh informan AW sebagai berikut:

"Panti Sosial Karya Wanita ini kita menggunakan beberapa jenis bentuk pembinaan sosial, seperti bimbingan sosial, bimbingan fisik, bimbingan mental dan bimbingan vokasional. Jenis bimbingan yang digunakan di sisni sebagaimana diterapkan oleh Kementrian Sosial dalam menangani masalah tentang penanganan klien yang dibina di panti rehabilitasi. Akan tetapi, skala prioritas dalam pembinaan adalah pembinaan keagamaan atau bimbingan mental, dengan alasan kalau mental klien sudah terarah dan sadar akan perbuatan yang mereka telah lakukan, maka keterampilan apa pun yang didapat, ia akan mampu mengaplikasikan di tengah-tengah kehidupan masyarakat". 8

Rehabilitasi sosial dilakukan sebagai bentuk layanan kepada klien yang membutuhkan layanan khusus di bidang sosial, maka perlu adanya upaya untuk meningkatkan kemampuan bersosialisasi, mencegah agar kemampuan sosialnya tidak menurun, dan kalau tidak maka akan lebih parah dari kondisi sosial sebelumnya. ${ }^{9}$

Kegiatan rehabilitas sosial yang dilakukan di Panti Sosial Karya Wanita Mattirodeceng dilakukan dalam beberapa tahapan yaitu tahap penerimaan, assesmen, intervensi, dan terminasi, sehingga klien terlebih dahulu diidentifikasi untuk mengetahui latar belakang keluarga klien, potensi setiap klien, umur, tingkat pendidikan, agama, status perkawinan, dan status sosial ekonominya. Selain itu, juga diselidiki penyebab mereka terjerumus kedalam praktek pekerja seks komersial. Hal tersebut senada dengan yang disampaikan informan JL sebagai brikut:

"Sebelum mendapatkan rehabilitasi, pihak panti akan melakukan beberapa tahap untuk mengetahui tentang kehidupan klien, seperti latar belakang keluarga, potensi, umur, pendidikan, agama, stat us perkawinan, status sosial dan penyebab mereka masuk dalam praktek pekerja seks komersial. Ini dilakukan agar pekerja sosial lebih dekat dengan mereka dan mudah untuk membagi kelompok mereka dalam tingkat keterampilan dan usia. Ini juga

\footnotetext{
${ }^{8}$ Hj. Anugrahwati (44 tahun), Pekerja Sosial, Wawancara, di Panti Rehabilitasi Mattirodeceng Kota Makassar 18 Agustus 2017.

${ }^{9}$ Pusat Penelitian Bahasa,Kamus Besar Bahasa Indonesia (Bandung: CV. Toha Putra,1998), h.92.
} 
dimaksudkan agar upaya mencegah mereka kembali keprofesinya setelah mengetahui penyebab mereka terjerumus ke dalam dunia kesesatan". ${ }^{10}$

Ada beberapa hal yang dipersiapkan pekerja sosial dalam bimbingan sosial pada klien di Panti Sosial Karya Wanita Mattirodeceng Kota Makassar yaitu integritas diri dan materi dakwah yang disampaikan kepada klien. Persoalan integritas bermakna kesesuaian antara nilai atau norma dengan realias ketulasan hati pekerja sosial dalam menyampaikan pesan-pesan yang bermuatan dakwah terhadap klien yang akan menimbulkan rasa hormat, penghargaan, simpati, maupun dukungan terhadap pekerja sosial. Dengan demikian pekerja sosial dengan kepiawaiannya dalam menyampaikan pesan dakwah dengan keteladanan, ketulusan hati, kasih sayang terhadap klien, selanjutnya pada lapisan kedua adalah kapabilitas, yang meliputi keahlian, pengalaman dan kesanggupan mengemban amanah dakwah. Perpaduan antara kedua modal tersebut akan menjadikan pekerja sosial sebagai teladan yang kharismatik.

Materi dan penyajian dakwah merupakan pesan yang berimplikasi pada bentuk aktivitas komunikasi dalam dakwah yang disajikan secara relevan dengan kondisi dan kebutuhan klien, materi yang tidak sesuai dengan kebutuhan klien tentu diabaikan, sehingga tidak memberi hasil positif sebagaimana target yang diharapkan.

Penyajian dengan model dan metode dakwah dikemas dalam bentuk dialog interaktif, diskusi atau dalam bentuk penyajian pesan dengan menggunakan bahasa verbal, kata-kata yang disampaikan dengan cara tertentu akan memiliki kekuatan yang luar biasa untuk memengaruhi dan mengubah perilaku manusia. Demikian pula, bilamana hal itu bersinergi dengan logika maka akan berpengaruh terhadap berbagai pengambilan keputusan penting dalam kehidupan individu maupun masyarakat luas. Kekuatan kata-kata (dalam bentuk lisan maupun tulisan) dapat menjadi stimulan yang merangsang respon psikologis klien.

Al-Qur'an memberikan pedoman tentang komunikasi persuasif yang terwujud dalam berbagai jenis perkataan, antara lain: qaulan baligha (perkataan yang membekas pada jiwa), qaulan ma'rufa (perkataan yang baik), qaulan sadida (perkataan yang benar: QS. al-Ahzab/33: 70), qaulan layyina (perkataan yang lemah lembut: QS. Thaha/20:44), qaulan karima (perkataan yang mulia: QS. al-Isra/17:23), qaulan maisura (perkataan yang ringan, mudah: QS. al-Isra/17:28), Qaulan tsaqila (perkataan yang berat: QS. al-Muzammil/73:5), qaulan adzima (perkataan yang agung).

Setiap jenis perkatan memiliki karakteristik tertentu dan ditujukan untuk klien dengan tujuan agar klien memahami dan menerima seruan dakwah dengan sebaikbaiknya. Wilbur Schramm mengidentifikasi adanya empat faktor yang memengaruhi penerimaan pesan dalam proses komunikasi yaitu kemampuan menerima dari komunikan, proses saling memengaruhi. Semakin intensif komunikasi maka akan semakin intensif pula interaksi sosial sehingga proses saling mempengaruhi akan semakin besar.

2. Penyampaian dakwah persuasif dalam bentuk bimbingan lanjutan

Bentuk bimbingan yang dilakukan oleh pekerja sosial setelah klien mendapat bimbingan sosial ditempat pembinaan eks pekerja seks komersial di Panti Sosial Karya Wanita Mattirodeceng Kota Makassar yaitu bimbingan lanjut.

Menurut Kementerian Sosial Republik Indonesia mengungkapkan bahwa bimbingan lanjut merupakan rangkaian kegiatan penyelenggaraan kesejahteraan sosial

\footnotetext{
${ }^{10}$ Juliana S.Sos (54 tahun). Pekerja Sosial, Wawancara, di panti rehabilitasi mattirideceng kota Makassar pada tanggal, 22 Agustus 2017.
} 
sebagai upaya untuk lebih memantapkan kemandirian klien, baik berupa konsultasi, bimbingan sebagai bantuan ulang, bimbingan peningkatan atau pengembangan skill maupun petunjuk lain untuk memperkuat kondisi kehidupan klien dalam bermasyarakat. ${ }^{11}$

Berdasarkan hasil wawancara bahwa sebelum klien mendapatkan rehabilitasi, maka tahapan yang dilakukan adalah melakukan pendekatan dengan klien untuk mengetahui keterampilan apa saja yang dimiliki klien. Tahap ini dilakukan untuk memberikan bimbingan lanjutan berupa pemberian keterampilan sesuai dengan peminatan klien (eks pekerja seks komersial).

\section{Penerapan dakwah persuasif dalam bentuk fardiyah}

Adapun penerapan dakwah persuasif adalah dalam bentuk dakwah fardiyah yang dilakukan oleh pekerja sosial sebagai pembina kerohanian pada eks pekerja seks komersial di Panti Sosial Karya Wanita Mattirodeceng Kota Makassar dapat diurai berdasarkan hasil pengamatan dan wawancara melalui dakwah persuasif. Oleh karena itu, maka dalam menyampaikan dakwah kepada eks pekerja seks komersial sebagai mad' $u$ atau klien adalah sebagai berikut:

a) Pembinaan dalam bentuk tablig Islam

Tablig berarti menyampaikan ajaran Islam sesuai dengan syariat dan tuntunan Rasulullah saw kepada klien dengan cara penyampaian keterangan yang jelas sehingga dapat diterima akal dan dapat ditangkap oleh hati. Sedangkan orang yang menyampaikan adalah pekerja sosial (Peksos) yang diamanahkan sebagai pembina keagamaan atau disebut muballig. Tugas utamanya adalah menyampaikan risalah dengan keterangan yang jelas, nyata dengan segenap kemampuan yang ada dengan menggunakan bahasa lisan maupun tulisan. Penerapan dakwah persuasif terebut dikenal sebagai prinsip suntikan (the inculation principle), yakni pekerja sosial yang ditugaskan dalam bidang keagamaan tentunya memberikan kebebasan klien menyampaikan pendapat, dan selanjutnya memberi pembenaran dan dukungan atas keyakinan dan pengetahuan yang dimiliki klien tentang pengetahuan agama yang dimiliki. Hal lain yang harus dimiliki pekerja sosial sebagai pembina keagamaan yaitu, memiliki kualifikasi pengetahuan tentang ajaran Islam berdasarkan Alquran dan alHadis, dengan alasan bahwa Alquran berfungsi sebagai petunjuk hidup, nasihat bagi yang membutuhkan pelajaran. Oleh karena itu, Alquran harus selalu dijadikan rujukan dalam menghadapi segala macam persoalan yang dihadapi klien (eks pekerja seks komersial).

Berdasarkan hasil pengamatan dan wawancara peneliti, bahwa ada beberapa aspek dakwah yang dilakukan para pekerja sosial yang terkait dengan penerapan dakwah persuasif dalam bentuk pembinaan tablig Islam yang berdasar pada tupoksi dalam hal pembinaan dakwah secara persuasif dalam menjalankan misi dakwah pada klien di Panti Sosial Karya Wanita Mattirodeceng Kota Makassar sebagai berikut:

1). Pembinaan dalam bentuk Taujuyah.

Pembinaan yang dilakukan terhadap eks pekerja seks komersial di Panti Sosial Karya Wanita Mattirodeceng Kota Makassar menjadi harapan setiap klien baik dari aspek pembinaan jasmaniah maupun rohaniah, secara realitas bila keberadaan klien tidak ditangani secara tepat, tidak terarah dan tidak berkesinambungan maka dapat berdampak pada keresahan masyarakat. Di samping itu, ada pola penanganan melalui

\footnotetext{
${ }^{11}$ Profil Kementerian Sosial Republik Indonesia Tahun 2017
} 
sistem luar panti yang juga bersifat rehabilitatif dan resosialisasi melalui bimbingan sosial dan keterampilan. Bimbingan ini meliputi bimbingan mental, sosial dan keterampilan serta pemberian stimulan bantuan usaha. Bimbingan ini juga mencakup bimbingan kesehatan yang berdampak positif dan sebagai upaya untuk menangkal menyebarnya penyakit menular.

Resosialisasi dalam proses pembelajaran kepada klien dalam panti terdapat norma-norma aturan baru yang bersifat sukarela, di mana para klien harus rela tinggal untuk mengikuti proses pembinaan dan rehabilitasi. Institusi sebagai tempat tinggal sementara bagi klien, di dalamnya terdapat sejumlah individu dengan situasi yang sama-sama terputus hubungannya dari masyarakat luas untuk jangka waktu tertentu, bersama-sama menjalankan kehidupan yang terkungkung dan diatur secara formal. Hal tersebut senada yang disampaikan oleh informan MD sebagai berikut:

"Penerapan resosialisasi sebagai petugas PSKW Mattirodeceng tidak memaksakan kehendak terhadap klien. Di mana sebelum melakukan pembinaan terhadap klien, petugas harus pandai-pandai mengambil hati klien dengan cara melakukan pendekatan dan memberikan nasehat kepada klien. Kemudian, setelah klien merasa nyaman barulah kami memberikan pembinaan. Pembinaan yang kami berikan seperti pembinaan keterampilan berupa jahit mejahit dan pembinaan keagamaan terhadap klien"12

Mafhum dakwah sebagai bentuk usaha yang dilakukan pekerja sosial dalam mengenal dan menjaga hubungan baik dengan klien untuk menuntunnya ke jalan Allah sehingga klien mudah menerima dakwah. Berdasarkan hasil pengamatan peneliti, yang sering dijumpai pekerja sosial keagamaan saat melakukan pembinaan terhasap klien yang bersifat mendalam yang terkait dengan pemahaman agama klien, pembinaan yang dilakukan tentu menimbulkan reaksi berupa ide yang bertentangan dengan cara pandang pekerja sosial dengan klien, tentunya langkah yang ditempuh pekerja sosial yaitu dengan menciptakan empati agar pekerja sosial mengenal situasi dan kondisi klien (mad'u). Hal tersebut senada yang disampaikan oleh informan AW, sebagai berikut:

"Setiap klien memiliki latar belakang yang berbeda di dalam pelaksanaan rehabilitas, dibutuhkan bimbingan khusus, seperti bimbingan sosial untuk membantu klien dalam proses interaksi terhadap lingkungan sosialnya. Oleh karena kebanyakan klien yang kami tangani tidak mudah bergaul dengan klien lain yang belum mereka kenal, menuntut pekerja sosial harus sabar menghadapi sikap klien yang berbeda-beda itu. ${ }^{13}$

Berdasarkan hal tersebut maka pekerja sosial melakukan bimbingan sosial (sosial work) yang merupakan metode pekerja sosial dalam melakukan rehabilitasi untuk memperbaiki dan meningkatkan mental dan fungsi sosial individu melalui interaksi-interaksi yang berlangsung. ${ }^{14}$ Setelah berhasil menjalin hubungan dengan masyarakat di panti rehabilitasi, maka ia memilih salah seorang dari mereka untuk

\footnotetext{
${ }^{12}$ Masdiana (53 tahun), Pekerja Sosial, Wawancara, di Panti Mattirodeceng pada tanggal, 22 Agustus 2017.

13 Anugrawati, (44 tahun). Pekerja Sosial, Wawancara, di Panti Rehabilitasi Mattirodeceng Kota Makassar Pada tanggal, 22 Agustus 2017.

${ }^{14}$ Robert W. klenle dan Robert M. Ryan, Bimbingan Sosial Kelompok http://S2.wp.com/:favicon.ico?m=13119760239.diakses tanggal 9 Oktober 2017.
} 
membina hubungan lebih dekat, menampakkan kecintaan dan perhatian. Menurut Sunaryo, bahwa empati yang ada pada seseorang memproyeksikan perasaannya dan emosinya kedalam objek pengalamannya, dengan kata lain empati merupakan kemampuan seseorang untuk menempatkan diri pada situasi orang lain, sehingga seorang muballig harus mengenal situasi dan kondisi yang berada pada mad'u atau klien. ${ }^{15}$

Bentuk bimbingan sosial yang dilakukan adalah merupakan serangkaian bimbingan yang dilakukan ke arah tatanan kerukunan dan kebersamaan hidup dalam masyarakat, sehingga diharapkan dapat menimbulkan kesadaran tanggung jawab terhadap klien. Hal tersebut senada yang disampaikan oleh informan MT, sebagai berikut:

"Bimbingan sosial mental yang dilakukan dalam memberikan efek positif sosial, dengan harapan agar klien dapat kembali hidup normal, menjalin hubungan baik dengan keluarga dan masyarakat dan mampu menjalankan fungsi sosialnya dengan penuh tanggung jawab di masyarakat. ${ }^{16}$

Bimbingan sosial bertujuan memberikan pandangan kepada klien tentang cara hidup dengan baik. Menjalankan fungsi sosial dan bertanggung jawab untuk diri sendiri maupun lingkungannya, menjalin hubungan dan kerjasama yang baik dengan keluarga maupun masyarakat sekitarnya. Permasalahan paling utama dan paling sulit untuk diperbaiki dalam diri eks pekerja seks komersial adalah berkaitan dengan kondisi mental.

Berdasarkan hasil pengamatan dan wawancara peneliti pada klien menunjukkan bahwa kebanyakan dari mereka berpikir bahwa dalam panti rehabilitasi kita dengan mudah memeroleh uang tanpa harus bekerja keras. Keadaan seperti ini membutuhkan upaya keras untuk mengembalikan pikiran dan kebiasaan mereka kearah yang benar. Hal tersebut senada yang disampaikan informan MD, sebagai berikut:

"Bimbingan mental sangatlah penting dalam rehabilitasi sosial di PSKW Mattirodeceng, untuk menangani masalah pekerja seks komersial. Dengan bimbingan mental diharapkan pola pikir dan kebiasaan buruk para eks pekerja seks komersial dapat berubah kearah yang lebih baik, terutama pola pikir mereka tentang bagaimana menghasilkan uang dengan mudah tanpa harus bekerja keras."17

Keberhasilan dari kegiatan bimbingan mental tergantung diri pribadi masingmasing klien. Perubahan pola pikir seseorang tergantung dari pandangan mereka tentang apa yang mereka lihat dan mereka dengar. Jadi bimbingan mental itu dapat berhasil jika klien memiliki keinginan untuk merubah pola yang lama ke pola hidup baru yang lebih baik. Menurut Qemi Abdurrahman bahwa Pay of idea merupakan usaha terhadap seseorang dengan memberi reward (hadiah, ganjaran bahkan harapan) yang

\footnotetext{
${ }^{15}$ Bambang Syamsul Arifin, Psikologi Agama, (Bandung: CV. Pustaka Setia, 2008), hal 48

${ }^{16}$ Muh Tahir, (53 tahun), Pekerja Sosial, Wawancara, di Panti Sosial Karya Wanita Mattirodeceng Kota Makassar, pada tanggal 10 September 2017.

${ }^{17}$ Masdiana, (53 tahun), Pekerja Sosial, Wawancara, di Panti Rehabilitasi Mattirodeceng pada tanggal, tangal, 22 Agustus 2017.
} 
baik. Sedangkan fear rousing yaitu menyajikan sesuatu message yang dapat menimbulkan rasa khawatir atau takut. ${ }^{18}$

Hal tersebut menunjukkan bahwa dengan memberikan penghargaan atau reward terhadap seseorang atau klien adalah merupakan salah satu cara untuk memotivasi seseorang menjadi lebih baik sesuai dengan apa yang menjadi tujuan dari sebuah pembinaan atau rehabilitasi dalam sebuah institusi atau bahkan dalam sebuah panti yang melakukan upaya menjadikan seseorang melakukan perubahan dengan dalih kesadaran yang didasarkan pada keinginan atau kemauan klien sendiri.

2). Pembinaan dalam bentuk tablig kitabah.

Penyampaian dakwah yang dilakukan kepada pekerja sosial secara konvensional dengan cara khitabah yaitu berkomunikasi secara langsung pada klien. Metode khitabah ini dilakukan dengan proses tersurat antara pembinaan keagamaan yang berstatus pekerja sosial kepada yang menjadi madh'unya, misalnya menuliskan bacaan salat maupun doa sehari hari pada klien. Hal tersebut sesuai apa yang disampaikan oleh informan MD, sebagai berikut:

"Pembimbing mental melalui cara menuliskan apa yang mereka tidak ketahui sangatlah penting dalam rehabilitasi sosial di PSKW Mattirodeceng, sebagai upaya menangani masalah ketidaktahuan membaca Alquran. Dengan bimbingan seperti tersebut diharapkan pola pikir dan kebiasaan buruk PSK dapat berubah kearah yang lebih baik, terutama pola pikir mereka tentang menghasilkan uang dengan mudah tanpa harus bekerja keras lewat pekerjaan yang haram." 19

Pembinaan dengan tablig khitabah yang dilakukan oleh pekerja sosial, diawali dengan melakukan identifikasi pada klien di Panti Sosial Karya Wanita Mattirodeceng Kota Makassar. Dengan pengetahuan agama yang dimiliki, seperti dapat membaca Alquran, menghafal bacaan shalat dan tata cara shalat serta taharah. Hal tersebut dilakukan pekerja sosial dengan penuh ketulusan. Olehnya itu sikap suka rela dalam penerimaan massage dakwah yang didasarkan atas pandangan psikologi yang merupakan ciri khas dari sifat persuasif (memberikan keyakinan), motivatif (merangsang), konsultatif (memberikan nasehat), serta edukatif (mendidik). ${ }^{20}$

Oleh karena itu, berdakwah dengan cara khitabah pada klien yakni menebarkan pesan-pesan keagamaannya dengan menggunakan kaidah-kaidah bahasa yang indah sehingga klien tertarik untuk membacanya. Bentuk Khitabah atau menulis yang dilakukan pekerja sosial pada klien di Panti Sosial Mattirodeceng adalah suatu proses kreatif yang banyak melibatkan klien.

Pelaksanaan khitabah atau menulis yang dilakukan pekerja sosial baik itu membaca maupun menulis Alqur'an kepada klien dengan menggunakan tehnik ketaatan. Ketaatan yang dimaksud adalah apa yang diajarkan pekerja sosial baik itu membaca maupun menulis senantiasa diikuti klien, akan tetapi jika klien tidak mengikuti maka strategi persuasif yang dilakukan pekerja sosial adalah tehnik ganjaran (pay of technique) atau hukuman (punishment) agar klien dapat memahami

\footnotetext{
${ }^{18}$ Oemi Abdurrahman, 1986, hlm 70-71

${ }^{19}$ Masdiana, (53 tahun), Pekerja Sosial, Wawancara, di Panti Rehab ilitasi pada tanggal, 22 Agustus 2017

${ }^{20}$ Arifin, M. Psikologi Dakwah Suatu Pengantar Studi, (Jakarta: Bulan Bintang. 1977), h. 17.
} 
tentang fungsi dan makna membaca alqur'an. Hal tersebut senada yang disampaikan informan MT sebagai berikut:

"Pembinaan metode baca tulis Alqur'an yang diterapkan di panti sosial rehabilitasi merupakan hal yang sudah diprogramkan sehabis melaksanakan shalat dan merupakan kewajiban setiap klien. Disamping itu belajar menulis alquran, hal tersebut dilakukan agar klien memiliki modal kesadaran jika ia sudah kembali ditengah tengah masyarakat dimana ia berdomisili." ${ }^{21}$

Kesuksesan pelajaran kitabah tergantung pada situasi dan kondisi belajar para eks wanita tuna susila. Kesemuanya itu tergantung pada mafhum tanzimi yang meliputi: pengarahan (tanzih) berupa bimbingan yang dilakukan pekerja sosial kepada mad'u (klien) dalam rangka berdakwah untuk membantu memahami keadaan dirinya, memahami persoalan-persoalan dan hambatan-hambatan yang dihadapinya.

Para pekerja sosial dalam menjalankan tugasnya di Panti Sosial Karya Wanita Mattirodeceng Kota Makassar, mereka melaksanakan dakwah secara khitabah kepada klien dengan menggunakan metode pendekatan dakwah persuasif. Dengan demikian, maka tulisan atau goresan pena seseorang penulis dapat menjadi pelopor suatu pikiran, keyakinan, ide, cita-cita, bahkan revolusi. ${ }^{22}$

Berdasarkan pengamatan dan hasil wawancara bahwa bentuk pembinaan tablig khitabah kepada klien tentunya diawali beberapa kegiatan, seperti melakukan pendekatan mafhum dakwah awal dalam bentuk orientasi dan konsultasi, kemudian melakukan identifikasi, memberi motivasi kepada klien agar ada semangat belajar, dan seleksi tingkat pemahaman keagamaan maupun keterampilan sebagai alat ukur yang digunakan para pekerja sosial dalam mempersiapkan pembinaan selanjutnya.

Ada beberapa tahapan yang dilakukan secara rinci pekerja sosial dalam hal pembinaan keagamaan kepada klien, sebagai berikut:

1) Tahapan Pelaksanaan.

Pada tahapan pelaksanaan, pekerja sosial; mengidentifikasi identitas klien secara jelas sehingga dapat merespon hasil dari pelaksanaan khitabah. Di dalam penyampaian materi tertentu, harus menggunakan media, agar para klien saat menerima bimbingan keagamaan dengan menggunakan media seperti buku-buku agama atau buku umum, akan lebih memudahkan klien mengerti dan memahaminya. Kegiatan dakwah persuasif yang dilakukan pekerja sosial akan menghasilkan hasil yang maksimal, disamping itu pekerja sosial berusaha membangkitkan attention (perhatian) dan kemudian interest (minat), sesuai dengan harapan pekerja sosial.

Selain itu, pekerja sosial yang melakukan pembimbingan melalui khitabah agar menyerap informasi dari referensi lain. Hal ini bertujuan agar informasi yang disampaikan bersifat objektif tidak subjektif. Pekerja sosial harus mengetahui apa yang diinstruksikan dan diinginkan dalam buku tersebut. Oleh karena itu, pekerja sosial harus lebih mengetahui kondisi dan keadaan klien.

2) Tahapan monitoring.

Monitoring di sini, adalah tugas Kepala Tata Usaha Panti Sosial Mattirodeceng yang senantiasa melakukan kontrol atas berjalannya tabligh secara khitabah yang dilakukan pekerja sosial. Melakukan pemantauan sejauh mana pembinaan dan

\footnotetext{
${ }^{21}$ Masdiana, (53 tahun), Pekerja Sosial, Wawancara, di Panti Rehab ilitasi pada tanggal, 22 Agustus 2017.

${ }^{22}$ Isa Anshary, Visi Misi Dakwah (Bandung: PT. Rosdakarya, 1984), h 33
} 
pendampingan yang dilakukan pekerja sosial terkhusus dalam hal pembinaan keagamaan pada klien di Panti Sosial Mattirodeceng. Dengan demikain setiap kegiatan yang dilakukan pekerja sosial selalu dibawah pengawasan seperti hanya kegiatan kerohanian yang dilakukan pekerja sosial kepada klien seperti kegiatan shalat berjamaah, praktek shalat, membaca alqur'an.

3) Tahapan evaluasi.

Tahapan evaluasi ini dilakukan untuk mengetahui feedback dari mad'u yang telah menerima pesan-pesan dakwah atau tablig khitabah. Evaluasi berguna sebagai masukan agar perkembangan atau penjelasan agama saat bimbingan belajar Alquran, ke depannya menjadi lebih baik. Hal tersebut senada yang disampaikan oleh informan JL, sebagai berikut:

"Pembinaan agama sangat penting dalam rehabilitasi sosial di PSKW Mattirodeceng, sebab dengan pembinaan agama, masalah klien dapat dengan mudah ditangani. Di samping itu, pelaku dakwah memang sangat mengharapkan pola pikir dan kebiasaan buruk para klien dapat berubah kearah yang lebih baik, terutama pola pikir mereka tentang cara menghasilkan uang dengan mudah tanpa harus menjual diri, demikian juga bimbingan keterampilan maupun penyadaran diri merupakan bekal agar tidak kembali lagi pada profesinya sebagai pekerja seks komersial ${ }^{23}$

Pekerja sosial tentunya memiliki tehnik tersendiri yang konsisten dengan pesan kebenaran dan didukung oleh integritas pribadinya sebab dakwah yang disampaikan bukan hanya membangun dan membina kepribadian dan pengetahuan klien akan tetapi juga membangun dirinya, yakni meningkatkan integritas dirinya maka kekeliruan-kekeliruan yang dilakukan dalam berdakwah (teknis, metode, strategi) dapat berjalan dengan baik. Pelaksanaan dakwah persuasif merupakan tehnik atau pendekatan yang harus digunakan oleh pekerja sosial, sehingga pekerja sosial ditunt ut memiliki kriteria-kriteria yang dipandang positif.

b) Pembinaan dalam bentuk Irsyad Islam.

Pembinaan yang dilakukan dengan dakwah secara Irsyad Islam yang dilakukan pekerja sosial terhadap proses bimbingan dan pengajaran yakni memberikan nasehat dan petunjuk kepada klien. Pembinaan dakwah dalam bentuk irsyad tent unya memiliki sasaran tertentu yang terkait dengan doktrinitas keislaman pada diri klien.

Penekanan dakwah persuasif secara irsyad, lebih berorientasi pada pemecahan masalah yang dialami klien, sebagai pekerja sosial yang diamanahkan oleh Dinas Sosial Provinsi Sulawesi Selatan tentunya setiap masalah yang dialami klien senantiasa memberikan jalan keluar dengan menggunakan metode intervensi seperti mengintervensi klien yang membuat mereka terjerumus ke lembah kesesatan, kemudian memberi solusi lewat nasehat agama terhadap masalah yang dihadapi. Hal tersebut senada dengan yang disampaikan oleh informan MT sebagai berikut:

"Sistem pengajaran dalam pendekatan dakwah persuasif melalui nasehat-nasehat agama, maupun menyangkut kegiatan keterampilan dan pembinaan sosial

${ }^{23}$ Juliana (54 tahun), Pekerja Sosial di Panti Sosial Karya Wanita Mattirodeceng Kota Makassar, Wawancara, di Panti Rehabilitasi Mattirodeceng Kota Makassar pada tanggal, 22 Agustus 2017. 
lainnya, sebab prinsip-prinsip dakwah tetap saya tanamkan dalam diri agar semua tindakan, sikap dan perbuatan akan tetap terjaga dan terkontrol dengan baik. ${ }^{24}$

Selain itu, penyampaian pesan dakwah yang dilakukan pekerja sosial kepada klien dengan bentuk irsyad Islam di Mattirodeceng merupakan paket program yang dirancang oleh pelaku dakwah dengan membimbing klien dua atau tiga orang sebagai kelompok kecil dengan memberikan solusi atas permasalahan kejiwaan yang dihadapi sebagai salah satu bentuk metode dakwah persuasif. Ada beberapa kegiatan yang dilakukan pekerja sosial dalam bentuk dakwah persuasif kepada klien lewat kegiatan dakwah irsyad sebagai berikut:

1) Kegiatan bimbingan dakwah

Sistem bimbingan dakwah irsyad yang dilakukan pekerja sosial kepada klien, menekankan pada prinsip-prinsip dasar Islam yang dimulai dari dasar-dasar pengamalan ajaran Islam. Kemudian dilanjutkan dengan mempelajari teori-teori dasar agama dengan maksud memberikan bekal pemahaman dan wawasan mengenai ajaran Islam sehingga dapat membantu klien dalam melaksanakan aktivitasnya. Ada beberapa bentuk pencerahan agama yang dilakukan pekerja sosial terhadap bimbingan dakwah yaitu:

(a) Bimbingan mental.

Bimbingan mental yang dilakukan bertujuan untuk membimbing dan memperbaiki mental psikologi klien dalam meningkatkan semangat hidup agar mereka mampu mengangkat harkat dan martabat diri mereka sendiri dalam menjalani kehidupan yang lebih baik dan layak. Kegiatan yang dilakukan pekerja sosial pada klien adalah: bimbingan mental, dinamika kelompok, bimbingan perorangan (konseling), serta bimbingan keagamaan. Mafhum tanzimi yang meliputi pengarahan (tanzih) bimbingan pekerja sosial kepada klien dalam rangka membantu klien memahami keadaan dirinya, memahami persoalan dan hambatan yang dihadapi, memahami tentang kemampuan dan kelebihan yang dimiliki klien.

Bimbingan mental yang dilakukan para pekerja sosial terhadap eks pekerja seks komersial pada Panti Sosial Karya wanita Mattirideceng sangatlah penting, bimbingan mental dilakukan melalui bimbingan hubungan personal dengan klien secara internalisasi dan transmisi untuk memberikan solusi atas permasalahan yang dihadapi dengan harapan pola pikir dan kebiasaan buruk pada diri klien dapat berubah kearah yang lebih baik. Hal tersebut di atas senada yang disampaikan oleh informan MD sebagai berikut:

"Kegiatan-kegiatan bimbingan yang dilakukan, tentunya kami sebagai petugas, banyak mengetahui faktor-faktor penyebab sehingga mereka terjerumus dalam dunia pelacuran. meskipun mereka berbeda, tetapi kebanyakan mereka melakukan hal itu karena sebab yang sama, seperti karena dorongan ekonomi yang sulit. Sebagian lagi karena pergaulan bebas dan pengaruh lingkungan yang tidak harmonis." 25

Kegiatan bimbingan mental yang dilakukan pekerja sosial, akan memudahkan memahami masalah-masalah yang dihadapi klien seperti sebab-sebab hingga terjun ke

\footnotetext{
${ }^{24}$ Muh Tahir (53 tahun), Pekerja Sosial, Wawancara, di Panti Sosial Karya Wanita Mattirodeceng Kota Makassar, tanggal, 10 September 2017.

25 Masdiana (53 tahun), Pekerja Sosial, Wawancara di Panti Sosial Karya Wanita Mattirodeceng tanggal, 22 Agustus 2017.
} 
dunia pekerja seks komersial. Isi bimbingan tersebut lebih menekankan pada kedekatan pekerja sosial dengan klien, agar supaya para eks pekerja seks komersial dapat terbuka menginformasikan penyebab dirinya terjerumus ke dalam dunia pekerja seks komersial. Hal tersebut senada dengan yang disampaikan oleh informan JL, sebagai berikut:

"Saat indetifikasi dilakukan, terlebih dahulu melakukan dengan pendekatan yang lebih dalam agar klien merasa tidak canggung untuk berbicara jujur dan menjelaskan penyebab mereka terjerumus dalam dunia pelacuran. Dalam hal ini, pekerja sosial akan lebih banyak mendengarkan tentang apa yang dikatakan oleh para klien dan memberikan sedikit masukan agar klien mudah mengerti dan tidak merasa tertekan selama berada di dalam panti menjalani konseling rehabilitasi. ${ }^{26}$

Pembinaan melalui dakwah yang dilakukan pekerja sosial, tidak terlepas dari aspek irsyad Islam, dengan tujuan agar klien lebih mendekatkan diri pada Tuhan dan menyadari kesalahan bahwa apa yang mereka lakukan selama ini tidak benar. Alquran mengajarkan tentang seluruh aspek ajaran Islam seperti rukun iman, shalat, puasa, zakat dan metode membaca Alquran. Sedangkan bagi yang beragama selain Islam dilakukan sesuai dengan ajaran agama masing-masing. Dengan demikian pendekatan dakwah persuasif bertujuan mengubah, memodifikasi atau membentuk respon (sikap atau perilaku) pada diri klien ${ }^{27}$

Berdasarkan hasil pengamatan dan wawancara peneliti kepada klien bahwa bimbingan yang dilakukan pekerja sosial berdasarkan latar belakang kondisi kehidupan klien, seperti penjelasan tentang hidup yang baik sesuai ajaran agama, cara berpakaian yang baik dan berbicara sopan. Selain itu, pelaku dakwah mengajarkan sesuatu yang boleh dilakukan dan tidak boleh dilakukan dalam pandangan agama Islam termasuk cara hidup yang baik dalam masyarakat.

Pelaksanaan bimbingan itu dilakukan pada hari sabtu dan minggu. Kegiatan bimbingan mental berupa dinamika kelompok, pelaksanaannya dilakukan diluar ruangan, yaitu di halaman Asrama eks pekerja seks komersial di Panti Sosial Karya Wanita Mattirodeceng. Kegiatan tersebut berupa permainan yang dapat membangkitkan solidaritas, motivasi dalam kelompok, dan permainan yang dapat membangkitkan suasana belajar yang bersifat keagamaan dan waktu pelaksanaannya setiap hari selasa dan rabu.

(b) Psikoterapi

Psikoterapi Islam merupakan salah satu bentuk kegiatan yang dilakukan pekerja sosial untuk membantu klien dalam memahami dirinya, mengetahui sumber psikopatologi dan kesulitan intuk menyesuaikan diri serta memberikan pandangan masa depan yang lebih cerah. Dengan psikoterapi ini juga diharapkan para eks pekerja seks komersial dapat menentukan langkah-langkah yang praktis untuk pelaksaan pemulihan dari penyakit sosial yang dialami oleh pekerja seks komersial.

(c) Penyuluhan

Penyuluhan yang dilakukan pekerja sosial adalah dengan bimbingan membaca Alquran, serta keterampilan lain. Pekerja sosial yang bertugas sebagai penyuluh senantiasa membantu klien untuk menemukan solusi atas maslah yang dihadapi serta menunjukkan kepadanya tentang kewajiban-kewajiban yang harus dipenuhi. Tujuannya adalah untuk memberikan pemahaman kepada klien dengan dasar-dasar agama dan

\footnotetext{
${ }^{26}$ Juliana (54 tahun), Pekerja Sosial, Wawancara, di Panti Sosial Karya Wanita Matttirodeceng pada tanggal 22 Agustus 2017

${ }^{27}$ (file:///F:/234-psikologi-komunikasi-dakwah.htm
} 
prinsip-prinsip penyuluhan yang profesional, memberikan wawasan komprehensif dan integratif mengenai keterampilan hidup, agar klien dapat terampil dan mandiri. Hal tersebut senada yang disampaikan oleh informan MT sebagai berikut:

"Pekerja sosial yang ditugaskan dibagian keagamaan, tentunya harus menguasai psioterapi Islam, sebab terkadang klien mendapat penyakit seperti kerasukan roh jahat, sehingga saya sering melakukan terapi lewat bimbingan zikir dan tuntunan bacaan Alquran. Di samping itu, petugas melakukan penyuluhan beserta pekerja sosial lainnya memberikan bimbingan keterampilan, seperti membuat kue, menjahit pakaian maupun keterampilan lain, terkhusus pada aspek keagamaan adalah dengan memberikan bimbingan cara membaca Alquran yang benar. ${ }^{28}$

Pembinaan lewat dakwah irsyad yang dilakukan pekerja sosial kepada klien merupakan salah satu program di Panti Sosial Karya Wanita Mattirodeceng, hal tersebut dilakukan agar klien merasa mendapatkan perhatian atas keberadaanya baik itu dari aspek agama maupun jenis keterampilan yang dimiliki klien. Kegiatan pembinaan yang dilakukan pekerja sosial dengan harapan agar klien tidak akan mengulangi lagi profesinya sebagai pekerja seks komersial.

c) Tadbir Islam berupa manajemen kelembagaan.

Pembinaan yang dilakukan pekerja sosial dalam hal ini yang bertugas dibidang pembinaan agama di panti sosial karya wanita Mattirodeceng kota Makassar terhadap eks pekerja seks komersial bukan hanya dilakukan dalam bentuk penyuluhan dan bimbingan mental serta keterampilan tetapi yang tidak kalah pentingnya adalah pembinaan secara kelembagaan. Mereka dikelompokkan sesuai dengan klaster hukuman yang diberikan kepada mereka sehingga mereka muda menyatu dan berkesesuaian satu dengan yang lain. Disamping itu juga untuk meminimalisir terjadinya ketidakcocokan diantara mereka, sebab tidak menutup kemungkinan terjadi kesalahpahaman yang disebabkan oleh beragam karakter yang dimilikinya.

Hal ini sesuai dengan apa yang diutarakan oleh salah seorang pekerja sosial AW yang mengungkapkan bahwa sistem pengelolaan pengasramaan dikelompokkan sesuai dengan berat dan ringannya hukuman yang diberikan, mereka dikelompokkan dan ditempatkan pada salah satu kamar yang telah ditentukan dan jumlah penghuni setiap kamar empat orang dengan harapan supaya tidak sering terjadi keributan diantara mereka. $^{29}$

Tadbir yang dilakukan pekerja sosial dalam rangka rekayasa sosial dan pemberdayaan masyarakat terhadap kehidupan yang lebih baik, peningkatan kualitas sumber daya manusia dan pranata sosial keagamaan untuk menumbuhkan dan mengembangkan perekonomian serta kesejahteraan masyarakat. Upaya peningkatan kualitas aktivitas dakwah sangat berkaitan dengan usaha yang bertujuan untuk meningkatkan kualitas seluruh komponen yang terlibat dalam kegiatan dakwah, yaitu kualitas sumber daya pekerja sosial dan mad'u.

Dengan demikian yang diperhatikan pekerja sosial sebagai pelaku dakwah adalah bagaimana kegiatan dakwah itu direncanakan, karena suatu perencanaan yang baik harus didasarkan pada hasil penelitian lapangan secara objektif. Tahap

\footnotetext{
${ }^{28}$ Muh Tahir (53 tahun), Pekerja Sosial, Wawancara, di Panti Sosial Karya Wanita Mattirodeceng Kota Makassar, tanggal 10 September 2017

${ }^{29}$ Anugrahwati (44 tahun), Pekerja Sosial, Wawancara, di Panti Rehabilitasi Mattirodeceng Kota Makassar pada tanggal, 18 Agustus 2017.
} 
perencanaan dakwah sangat menentukan keberhasilan dakwah. Jika seorang pekerja sosial yang berstatus muballig pada suatu lembaga dakwah gagal dalam merumuskan perencanaan dakwah, maka dalam perpektif manajemen, berarti juga sedang merencanakan kagagalan. Sebuah ungkapan yang sangat terkenal dari dunia manajemen yaitu ; Those who fail to plain, plain to fail, siapa yang gagal dalam membuat rencana, berarti ia sedang merencanakan kegagalan.

Perencanaan dakwah yang dilakukan para petugas pekerja sosial tentunya dilakukan secara sistimatik kepada eks pekerja seks komersial di Panti Sosial Karya Wanita Mattirodeceng. Menfungsikan panti rehabilitasi sebagai tempat pembinaan agama kepada eks pekerja seks komersial berarti melaksanakan dakwah secara tadbir.

Berdasarkan hasil wawancara dan pengamatan peneliti kepada klien bahwa aspek pengembangan dan pembinaan dakwah pada klien kepada eks pekerja seks komersial di Panti Sosial Karya Wanita Mattirodeceng sebagai lembaga resmi, tentu didasarkan pada perencanaan atau perumusan rencana dakwah yang matang sebagai berikut:

1) Menetapkan tujuan dakwah.

Perencanaan itu dimulai dengan keputusan pekerja sosial tentang keinginan atau kebutuhan klien, sebab tanpa rumusan tujuan yang jelas, maka tentu dakwah tidak akan berhasil dengan baik, atau lembaga dakwah tidak dapat menggunakan sumber dayanya secara efektif.

2) Merumuskan langkah perencanaan sesuai keadaan.

Pemahaman dan identifikasi kondisi yang dihadapi klien di Panti sosial Mattirodeceng sangat penting untuk merumuskan dan menentukan langkah yang paling tepat untuk dilakukan. Berdasarkan data bahwa jumlah klien yang harus mendapatkan pembinaan keagamaan sebagai sasaran dakwah sekitar 120 eks pekerja seks komersial, jumlah tersebut sudah ditentukan oleh pihak Dinas Sosial Provinsi Sulawesi Selatan dengan alasan kapasitas lokasi panti rehabilitas yang terbatas.

3) Mengidentifikasi segala kemudahan dan hambatan.

Mengidentifikasi segala kebutuhan lembaga tempat eks pekerja seks komersial di Panti Sosial Karya Wanita Mattirodeceng, bertujuan untuk mengukur kemampuan pekerja sosial sebagai pembina keagamaan, agar target untuk mencapai tujuan dakwah lewat pendekatan persuasif dapat terlaksana dengan baik. Di samping itu, perlunya upaya mengidentifikasi hambatan-hambatan sebagai dasar dalam pelaksanaan pembinaan sosial terutama pembinaan keagamaan yang dilakukan pekerja sosial.

4) Mengembangkan rencana dakwah untuk pencapaian tujuan.

Tahap terakhir dalam proses perencanaan dakwah meliputi pengembangan berbagai alternatif kegiatan yang dilakukan pekerja sosial kepada eks pekerja seks komersial di Panti Sosial Karya Wanita Mattirodeceng. Di dalam upaya pencapaian tujuan, penilaian alternatif, dan pemilihan alternatif terbaik di antara berbagai alternatif yang ada, tentunya ditujukan pada klien agar dakwah persuasif lewat tadbir, klien dapat merasakan manfaat pembinaan yang dilakukan para pekerja sosial.

d) Pembinaan dengan Tathwir

Berdasarkan hasil pengamatan dan hasil wawancara peneliti bahwa pelaksanaan dakwah dalam aspek tathwir memunyai tiga tahap, yaitu tahap pengenalan, tahap pembentukan dan tahap pelaksanaan. Setelah tersentuh marhalah ta'rif (pengenalan) dan sebelum memasuki marhalah takwim, maka pekerja sosial melakukan pendalaman kepada klien untuk memahami kejiwaan klien, supaya cita-cita yang ingin dicapai dari 
marhalah takwim dapat diwujudkan. Tidak akan lahir kesungguhan dan ketekunan kecuali setelah dakwah itu menguasai akal dan pikirannya, sejalan dengan jiwa dan hatinya, menjadi darah dagingnya, menjadikan semangat yang menyala-nyala dan sukmanya berkobar-kobar untuk merealisasikanya di dalam kenyataan hidup. Hal tersebut senada yang disampaikan oleh informan MT, sebagai berikut:

"Pembinaan lewat bimbingan agama, diharapkan klien mendapat pencerahan untuk kembali hidup dengan baik, dapat menjalin hubungan baik dengan keluarga dan masyarakat, mampu menjalankan fungsi sosial dan tanggung jawabnya di masyarakat. Pembinaan keagamaan merupakan salah satu inti di antara pembinaan yang lain, sebab dengan bimbingan agama khususnya agama Islam dapat lebih terarah aktifitasnya, di samping pembinaan keterampilan yang didapat klien di panti rehabilitasi merupakan bekal usaha nantinya di tengah masyarakat agar ia tidak terjerumus lagi pada pekerjaan yang menyesatkan." 30

Islam menghendaki individu yang mempunyai kemampuan membedakan mana yang benar dan mana yang salah. Islam mengajarkan supaya seseorang itu mempunyai kemauan yang tinggi dan tidak mengenal lelah, tidak setengah-setengah membela kebenaran. Oleh karena itu, Islam dan penganutnya harus memunyai badan yang sehat dan mampu memikul berbagai tugas dan kewajiban sebagai umat Islam dengan sebaikbaiknya.

Sesungguhnya marhalah di'ayah (penerangan), memperkenalkan, menggambarkan tentang dakwah dan cara penyampaiannya kepada klien, jika tidak diiringi dengan marhalah at-takwim (peringkat pembentukan dan pemilihan para pendukung dan penolong) serta persediaan fasilitas untuk mengatur dari kalangan orang-orang yang diseruh, kemungkinan menyebabkan segala usaha yang dilakukan jauh dari tujuan, penerangan dan penyebaran dakwah menjadi sia-sia dan hilang begitu saja, seperti halnya klien yang kurang mendapatkan sentuhan dakwah saat direhabilitasi, maka kemungkinan akan kembali ke habitatnya sebagai PSK.

Kesadaran rohani yang lahir dari marhalah ta'rif tidak boleh dibiarkan musnah begitu saja pada diri klein, tetapi mesti dibersihkan dan diarahkan ke dalam jiwa mereka supaya dapat bertindak dan berusaha membuat perubahan pada kemajuan yang sejati dalam diri mereka sendiri. Allah berfirmandalam QS. Ar-Ra'ad/13: 11

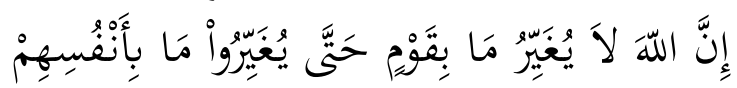

Terjemahnya:

"Sesungguhnya Allah tidak akan mengubah keadaan suatu kaum sehingga mereka mengubah apa yang ada pada diri mereka" ${ }^{31}$

Pelaksanaan dakwah dimaksudkan untuk menyeruh manusia ke jalan Allah dan mengajak manusia kepada cara hidup islami, harus mendapat perhatian dan usaha yang serius dalam membersihkan diri mereka dan menuntun mereka menghiasi diri dengan adat-adat yang islami. Sebagaimana firman Allah berfirman dalam QS. AlBaqarah/2:138 sebagai berikut:

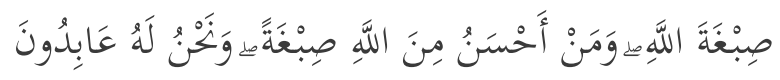

\footnotetext{
${ }^{30}$ Muh Tahir (53 tahun), Pekerja Sosial, Wawancara, di Panti Sosial Karya Wanita Mattirodeceng Kota Makassar, tanggal, 10 September 2017

${ }^{31}$ Kementerian Agama, Alquran dan Terjemahnya, h. 270.
} 
Terjemahnya:

"Dan siapakah yang lebih baik shibghahnya daripada Allah? Dan hanya kepada-Nyalah kami menyembah." ${ }^{32}$.

Aspek pembinaan lain adalah pembentukan akhlak yang baik. Sangat dikehendaki orang muslim supaya menjadi muslim yang lurus akidahnya, sehat ibadahnya, teguh akhlaknya, terdidik fikirannya, sanggup berdikari dan mau berkorban untuk dirinya sendiri dan orang lain, sanggup memerangi hawa nafsu, menjaga waktunya dengan sebaik-baiknya, berdisiplin dalam segala urusannya. Sesungguhnya upaya mempersiapkan klien yang unggul dan memunyai mutu memerlukan usaha yang sungguh-sungguh, ketekunan, kesabaran dan ketabahan yang utuh.

Dakwah dalam bentuk komunikasi persuasif yang dilakukan pekerja sosial kepada Eks Wanita Tuna Susila di Panti Rehabilitasi Mattirodeceng tanpa mengenal lelah, karena sesungguhnya jalan dakwah itu adalah jihad yang tidak boleh berhenti. Dakwah dan jihad adalah satu perjuangan yang berkelanjutan untuk sampai kepada tujuan. Tidak ada sesuatu yang menjamin kemenangan kecuali ketaatan dan persaudaraan yang kokoh yang berdiri di atas kasih sayang di antara sesama muslim. Tahap persaudaraan paling minim ialah terpeliharanya hati dari prasangka buruk terhadap saudara muslim. Setinggi-tinggi tahap persaudaraan itu ialah mengutamakan saudaranya yang muslim lebih dari daripada kepentingan dirinya sendiri.

Untuk mencapai hasil pembinaan, pekerja sosial melakukan beberapa upaya seperti: a) Menyusun jadwal pengajian, b) Merancang pertemuan-pertemuan tidak formal dalam upaya mempererat ukhuwah, contohnya salat berjamaah c) Jika terjadi salah paham antara sesama klien, maka pekerja sosial harus mengambil jalan tengah dan berusaha mengambil sikap dengan lapang dada.

Berdasarkan hasil pengamatan dan wawancara yang penulis lakukan, tentang implementasi dakwah persuasif, ada beberapa kemampuan yang harus dimiliki pekerja sosial dalam menghadapi Eks Wanita Tuna Susila di Panti Rehabilitasi Mattirodeceng dalam melaksanakan dakwahnya secara persuasif yaitu:

1) Memiliki kemampuan dalam berkomunikasi.

Mengomunikasikan pesan dakwah kepada mad'u, dapat dilakukan melalui lisan, tulisan atau perbuatan, dengan bahasa dan kata-kata atau dengan perbuatan. Komunikasi dapat berhasil manakala pesan dakwah itu dipahami oleh mad'u, dan pesan dakwah itu mudah dipahami manakala disampaikan sesuai dengan cara berfikir dan cara merasa mad'u. Jadi, seorang pekerja sosial yang berada di bagian pembinaan keagamaan, dituntut untuk dapat menggunakan metode yang tepat dalam mengomunikasikan pesan dakwahnya.

2) Memiliki kemampuan dalam melakukan bimbingan sosial.

Materi pembinaan sosial meliputi materi pendidikan kesadaran hukum, pengetahuan lingkungan hidup dan hubungan antar sesama manusia, bimbingan sosial pencegahan AIDS, dan kewirausahaan. Pemberian materi tersebut masing-masing mempunyai tujuan. Tujuan dimaksud dapat dilihat pada penjelasan berikut:

a) Materi kesadaran hukum yang diberikan kepada klien bertujuan agar klien mengetahui tanggung jawab mereka sebagai warga negara. Selain itu, mereka juga harus mengetahui peraturan-peraturan negara yang telah mereka langgar sehingga mereka sadar bahwa apa yang mereka lakukan selama ini telah membuat permasalahan bagi masyarakat. b) Materi pengetahuan lingkungan hidup dan hubungan antar

\footnotetext{
${ }^{32}$ Kementerian Agama, Alquran dan Terjemahnya, h. 22.
} 
manusia bertujuan untuk memberikan kesadaran bagi klien untuk tetap menjaga lingkungan disekitarnya dengan cara hidup sehat. Klien juga diajarkan untuk berhubungan baik dengan orang lain, berlaku sopan dan bertutur kata lembut agar terjalin hubungan silahturahmi yang baik di lingkungan mereka, juga menjelaskan tentang manusia sebagai makhluk sosial yang tidak dapat hidup sendiri dan membutuhkan orang lain untuk melanjutkan hidup dan menjalankan fungsi sosial mereka. c) Materi pencegahan AIDS adalah materi yang diberikan kepada klien yang bertujuan agar klien mengetahui tentang bahaya penyebaran penyakit AIDS, sehingga klien sadar bahwa yang selama ini mereka lakukan akan berisiko besar yang mengakibatkan mereka terkena penyakit berbahaya, dengan harapan agar mereka menyadari dan memutuskan untuk tidak lagi kembali menjadi PSK. Oleh karena itu, mereka perlu diberikan bimbingan materi kewirausahaan dengan tujuan untuk memberikan pengetahuan kepada para klien tentang bagaimana cara membuka usaha dan mengelola usaha agar ketika mereka keluar dari panti pembinaan, mereka bisa membuka usaha dan mengelolanya sendiri.

3) Memiliki kemampuan dalam pemberian bimbingan keterampilan

Pemberian bimbingan keterampilan berupa bimbingan tatarias, menjahit dan tataboga, maka bimbingan keterampilan ini diberikan bertujuan agar ketika klien keluar dari panti pembinaan, mereka dapat dan mampu mengaplikasikan pengetahuan keterampilan dalam membuka usaha sebagai mata pencaharian untuk memenuhi kebutuhan sehari-hari mereka, sehingga mereka tidak perlu lagi kembali ke pekerjaan mereka sebagai PSK.

Bimbingan keterampilan dalam hal tata rias yang diberikan kepada klien, melalui pengenalan alat tata rias, cara memotong dan menata rambut, praktek make up, praktek facial, dan creambath. Untuk keterampilan menjahit, klien diajarkan cara menjahit, evaluasi dasar menjahit, pengambilan ukuran pakaian, dan menggambar pola. Untuk tataboga, klien diajarkan cara membuat bumbu masak dan cara memasak masakan khas Sulawesi Selatan. Bukan hanya itu, klien juga diajarkan cara membuat berbagai macam kue.

Semua bentuk keterampilan yang diberikan kepada klien bukan hanya keterampilan yang dibutuhkan oleh eks Pekerja Seks Komersial tetapi juga dibutuhkan oleh masyarakat. Hal tersebut senada yang disampaikan oleh informan AW, sebagai berikut:

"Untuk bimbingan keterampilan, kami mengajarkan tentang keterampilanketerampilan yang juga menjadi kebutuhan di masyarakat, seperti tata rias, menjahit dan tata boga. Dalam hal tatarias, sekarang banyak orang yang mencari jasa rias wajah saat ingin ke pesta, pengantin atau wisuda dan tukang potong atau penata rambut di salon. Untuk keterampilan menjahit adalah jasa yang sangat dicari oleh masyarakat, banyak orang yang lebih senang menjahit baju buat ke pesta atau baju kantor mereka ke tukang jahit dan membuat model sesuai keinginan mereka ketimbang membeli pakaian jadi. Untuk tata boga, kita fokuskan untuk kuliner khas Sulawesi Selatan berupa masakan dan kue khas Makassar". 33

Pemberian bimbingan kepada klien, tidak hanya pembinaan fisik yang diperhatikan, melainkan juga pembinaan psikis. Di sini mental dihubungkan dengan

\footnotetext{
${ }^{33}$ Anugrahwati (44 tahun), Pekerja Sosial, Wawancara, di Panti Rehabilitasi Mattirodeceng Kota Makassar pada tanggal, 18 Agustus 2017.
} 
akal, fikiran dan ingatan. Oleh karena itu, akal harus dijaga dan dipelihara, karena dibutuhkan juga mental yang sehat. Hal tersebut senada yang disampaikan oleh informan JL sebagai beikut:

"Pelaksanaan program kegiatan keterampilan dan bimbingan di PSKW "Mattirodeceng" akan memberi dampak positif kepada para klien. Perubahan diri klien saat mengikuti berbagai pelaksanaan kegiatan keterampilan yang diberikan oleh pekerja sosial di PSKW "Mattirodeceng", para klien diharapkan mampu berkreasi dengan keterampilan yang yang mereka miliki. Selain dari keterampilannya, para klien juga diharapkan menjadi lebih bermoral berkat adanya bimbingan-bimbingan yang mereka pernah terima dari PSKW "Mattirodeceng yang dapat membuat mereka bisa hidup dengan tenang." 34

Sesungguhnya ketenangan hidup, ketentraman jiwa dan kebahagian hidup, tidak hanya tergantung pada faktor dari dalam saja tetapi juga dengan adanya pengaruh dari faktor luar, seperti ekonomi, jabatan, status sosial di masyarakat. Jadi yang menentukan ketenangan dan kebahagian hidup adalah kesehatan mental atau jiwa, kesehatan mental dan kemampuan menyesuaikan diri. Oleh karena itu, dakwah yang disampaikan lewat pendekatan persuasif dengan materi yang menyangkut pengaruh hidup tenang dapat memberikan ketenangan para klien dalam hidupnya sekalipun mereka memahami bahwa dirinya pernah terjerumus pada perbuatan yang memalukan. ${ }^{35}$

Jika dilihat dari berbagai sudut pandang, di mana rehabilitasi bukan hanya untuk menyembuhkan, tetapi juga berdaya guna di tengah-tengah masyarakat dalam melakoni hubungan sosial yang baik. Hal tersebut senada yang disampaikan oleh informan MD sebagai berikut:

"Sebahagian masyarakat memandang bahwa rehabilitasi itu hanya untuk orang sakit seperti pecandu narkoba, pada hal sesungguhnya wanita yang terlibat dalam prostitusi atau pelacuran juga membutuhkan rehabilitasi untuk memulihkan diri dari rasa kecanduan akan seks bebas. Oleh karena itulah, maka pemerintah telah menyediakan panti rehabilitasi dan segala fasilitas di dalamnya agar klien dapat merubah kehidupannya. ${ }^{36}$

Kenyataan tersebut di atas menunjukkan bahwa rehabilitasi bukan hanya untuk mereka yang sedang sakit, akan tetapi Wanita Tuna Susila juga membutuhkan rehabilitasi sebagai upaya menyembuhkan mereka dari penyakit seks, yang pada gilirannya mereka bisa kembali hidup normal di tengah-tengah masyarakat. Seseorang dapat melaksanakan fungsi sosialnya jika ia dapat berintegrasi dengan masyarakat lain dan memiliki kemampuan fisik, mental dan sosial yang baik. ${ }^{37}$

Hal ini menujukkan bahwa bentuk pembinaan yang dilakukan oleh pekerja sosial yang telah disusun sedemikian rupa serta melalui perencanaan yang matang yang kemudian diaplikasikan dalam kegiatan sehari-hari dengan tujuan agar supaya para eks pekerja seks komersial bisa menyadari apa yang telah dilakukannya dan ada kemauan

\footnotetext{
${ }^{34}$ Juliana (54 tahun), Pekerja Sosial, Wawancara, di Panti Rehabilitasi Mattirodeceng Kota Makassar pada tanggal, 22 Agustus 2017

${ }^{35}$ Hamdan Bakran Adz-Dzaky, Konseling dan Psikoterapi Islam (Yogyakarta: Fajar Pustaka, 2001), h. 8 .

${ }^{36}$ Masdiana (53 tahun), Pekerja Sosial, Wawancara, di Panti Rehabilitasi Mattirodeceng Kota Makassar tanggal 22 Agustus 2017

${ }^{37}$ Isbandi Rukminto Adi, Kesejahteraan Sosial (Jakarta: Rajawali Pers, 2013), h. 110
} 
untuk memperbaiki dirinya sebagai makhluk yang diciptakan oleh Allah yang ditugaskan untuk beribadah kepada Allah.

\section{PENUTUP}

Berdasarkan paparan di atas maka dapat disimpulkan bahwa bentuk penerapan dakwah persuasif terhadap pembinaan eks pekerja seks komersial yaitu; a). penyampaian dakwah persuasif dalam bentuk pemberian bimbingan sosial; integritas diri dan materi dakwah, b). penyampaian dakwah persuasif dalam bentuk bimbingan lanjutan, c). penerapan dakwah persuasif dalam bentuk fardiyah; pembinaan dalam bentuk tablig Islam, pembinaan dalam bentuk taujiyah, pembinaan dalam bentuk tablig khitabah, pembinaan dalam bentuk irsyad Islam; kegiatan bimbingan dakwah, pembinaan dengan takwim; memiliki kemampuan dalam berkomunikasi, memiliki kemampuan dalam melakukan bimbingan sosial, memiliki kemampuan dalam pemberian bimbingan keterampilan.

\section{DAFTAR PUSTAKA}

Kartono, Kartini, Patologi Sosial Jakarta: Rajawali Pers, 2009.

Badr, Syaikh 'Abdul Muhsin bin Hamd al-'Abbad al-, Kitab Fat-hul Qawiyyil Matin fi Syarhil Arba'in wa Tatimmatul Khamsin (Penjelasan 50 Hadits Inti Ajaran Islam), Penerjemah: Ustadz Abu Abdillah Arief Budiman, Lc,

Mahmud, Ali Abdul Halim, Dakwah Fardiyah, Metode Membentuk Pribadi Muslim. Jakarta: Gema Insani Press, 1995.

Enjang AS. dan Aliyudin. Dasar-Dasar Ilmu Dakwah. Bandung: Widya Padjajaran, 2009.

Kementerian Agama, Alquran dan Terjemahnya, Solo: PT. Tiga Serangkai Mandiri, 2013.

Jumantoro, Totok, Psikologi Dakwah Jakarta, 2001).

Pusat Penelitian Bahasa,Kamus Besar Bahasa Indonesia Bandung: CV. Toha Putra, 1998.

Klenle, Robert W. dan Robert M. Ryan, Bimbingan Sosial Kelompok http://S2.wp.com/:favicon.ico?m=13119760239.diakses tanggal 9 Oktober 2017.

Arifin, Bambang Syamsul, Psikologi Agama, Bandung: CV. Pustaka Setia, 2008.

Arifin, M. Psikologi Dakwah Suatu Pengantar Studi, Jakarta: Bulan Bintang. 1977.

Anshary, Isa, Visi Misi Dakwah Bandung: PT. Rosdakarya, 1984. 
Dzaky Hamdan Bakran Adz-, Konseling dan Psikoterapi Islam Yogyakarta: Fajar Pustaka, 2001.

Adi, Isbandi Rukminto, Kesejahteraan Sosial Jakarta: Rajawali Pers, 2013

\section{Sumber Wawancara}

Hj. Anugrahwati (44 tahun), Pekerja Sosial, Wawancara, di Panti Rehabilitasi Mattirodeceng Kota Makassar 18 Agustus 2017.

Masdiana (53 tahun), Pekerja Sosial, Wawancara, di Panti Rehabilitasi Mattirodeceng Kota Makassar tanggal 22 Agust us 2017.

Juliana S.Sos (54 tahun). Pekerja Sosial, Wawancara, di Panti Rehabilitasi Mattirideceng Kota Makassar pada tanggal, 22 Agustus 2017.

Anugrawati, (44 tahun). Pekerja Sosial, Wawancara, di Panti Rehabilitasi Mattirodeceng Kota Makassar Pada tanggal, 22 Agust us 2017.

Muh Tahir, (53 tahun), Pekerja Sosial, Wawancara, di Panti Sosial Karya Wanita Mattirodeceng Kota Makassar, pada tanggal 10 September 2017. 